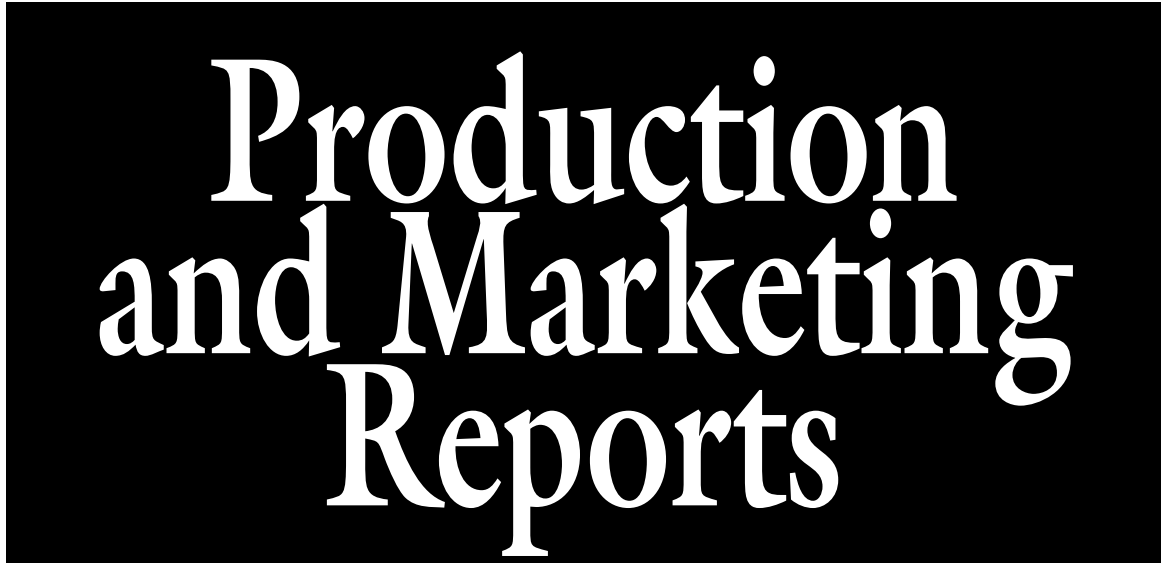

\section{Consumer Perception of Skinning Injury in Sweetpotatoes and Implications for Marketability: An Experimental Auction}

\author{
Alba J. Collart ${ }^{1}$, Stephen L. Meyers ${ }^{2,5}$, and Jason K. Ward ${ }^{3,4}$
}

\section{AdDitional INDEX wORDs. Ipomoea batatas, willingness-to-pay}

\begin{abstract}
Summary. Skinning of sweetpotato (Ipomoea batatas) storage roots is one of the greatest concerns of sweetpotato producers. Although skinning injury is very common, the severity of the injury can vary widely. At an undefined threshold, sweetpotatoes with skinning injury are no longer sold for fresh consumption. The objectives of this study were to examine how skinning injury influences consumers' willingness-to-pay (WTP) for sweetpotatoes and to identify differences in valuations when the extent of skinning injury is labeled. Image analysis was used to quantify skinning injury and then an incentive-compatible, nonhypothetical laboratory experimental auction was conducted to collect data on consumers' WTP for five categories of sweetpotatoes: $0 \%$ to $<1 \%$ skinning injury, $1.0 \%$ to $3.0 \%, 3.1 \%$ to $\mathbf{5 . 0} \%, \mathbf{5 . 1} \%$ to $7.5 \%$, and $7.6 \%$ to $10.0 \%$. On average, consumers were willing to pay the most for sweetpotatoes with $0 \%$ to $<1 \%$ skinning injury (up to $\$ 1.51 / 1 \mathrm{~b}$ to $\$ 1.67 / \mathrm{lb}$ ) and the least for sweetpotatoes with $7.6 \%$ to $10 \%$ (up to $\$ 0.76 / \mathrm{lb}$ to $\$ 0.85 / 1 b)$, yet mean WTP values were nonzero for all skinning levels. Moreover, when the extent of skinning was labeled (relative to when they bid blindly), consumers were willing to pay price premiums for sweetpotatoes with low skinning injury levels ( $0 \%$ to $5 \%$ ) and discounted sweetpotatoes with the highest skinning injury level $(7.6 \%$ to $10.0 \%)$, suggesting that skinning levels of $7.6 \%$ and above may not be acceptable by consumers.
\end{abstract}

$\mathrm{T}$ he sweetpotato industry contributes significantly to the U.S. agricultural economy. In 2018 , it harvested 144,400 acres nationally, which produced 27.4 million cwt valued at $\$ 654.1$ million [U.S. Department of Agriculture (USDA), 2018]. Although commercial production is concentrated in North Carolina, California, Mississippi, Louisiana, and Texas, skinning injury remains one of the greatest concerns to sweetpotato producers nationally (M.W. Shankle, unpublished data). Sweetpotato skin is relatively thin and easily sloughed off of storage roots during harvest, transport, packing, and stocking. At harvest,

skinning injury can create entry points for postharvest plant pathogens and allow for increased water loss, often causing roots to shrivel (Arancibia and LaBonte, 2013; Edmunds et al., 2008). Current recommendations to minimize skinning injury include devining (flail mowing sweetpotato foliage) 4 to $10 \mathrm{~d}$ before harvest and irrigating fields before harvest to "soften" the soil (Arancibia and LaBonte, 2013). In Mississippi, a limited number of sweetpotato growers have the ability to irrigate fields, and most rely solely on devining. Despite any preharvest treatment, most sweetpotatoes still experience at least one or two skinning wounds during the harvest operation (Wang et al., 2013). Wang et al. (2013) investigated changes in skinning severity in response to preharvest foliar applications in three different years and found that in sweetpotato plants devined 5 to $7 \mathrm{~d}$ before harvest, $80 \%$ to $100 \%$ of harvested sweetpotato storage roots were skinned.

Although skinning injury is very common, the percentage of sweetpotato storage root surface area affected by skinning injury can vary widely (Schultheis et al., 2000). Several researchers have attempted to quantify skinning injury severity with limited success and/or efficiency (Bouwkamp et al., 1972; Wright and LaBonte, 1994). Recently, Ward and McKee (2014) developed a consistent method of quantifying skinning injury. The method uses image analysis to estimate the skinning severity (percent skinned surface area) of a root. Images are collected using an off-theshelf digital color camera and the system uses color differences between root skin and flesh to segment the imagery into skinned and unskinned regions. Four images of each root are analyzed and a ratio of the total number of pixels classified as skinned to the total number of pixels in each root is calculated. The system is validated against simulated targets with known ratios and verified to have less than $2 \%$ error in estimated skinning incidence.

Skinning injury can contribute to postharvest losses, but can also result in losses of marketable products due only to unattractive marketable appearance (Wang et al., 2013). Skinning injury is considered to be aesthetically displeasing to consumers and can result in otherwise consumable fresh market sweetpotatoes being sold in processing markets at $20 \%$ or less of the fresh market price, assuming the producer has a processing contract. However, what is considered an allowable percentage of skinning is often determined by the produce retailer and may differ widely from what sweetpotato producers and packers may feel is acceptable. Ultimately, the marketability of fresh sweetpotatoes with varying degrees of skinning injury will be determined by consumers who often choose to purchase produce based on visual examination. A greater understanding of how skinning injury severity relates to 
consumer preferences is needed to establish a research-based threshold for fresh market marketability.

The objectives of this project were to estimate consumers' mean WTP for sweetpotatoes with varying amounts of skinning injury and to identify whether there are differences in valuations when the extent of skinning injury is made salient by labeling it. WTP was assessed by conducting a nonhypothetical, incentivecompatible laboratory experimental auction. Experimental auctions are regularly used by applied economists, psychologists, and marketers to valuate new products, technologies, and treatments (Alfnes and Rickersten, 2003, 2008; Lusk and Shogren, 2007). In horticulture research, they have been used to elicit consumer preferences for products and attributes, including cosmetic damage in organic apples [Malus $\times$ domestica (Yue et al., 2009)], biodegradable plant containers (Yue at al., 2010), labeled native and invasive plants (Yue et al., 2012), pomegranates [Punica ×granatum (McAdams et al., 2013)], energy and water efficiency in plant production (Yue et al., 2015), and quality attributes in 'Honeycrisp' apples (Gallardo et al., 2015). Although experimental auctions can be hypothetical, hypothetical auctions can sometimes suffer from hypothetical bias (List and Gallet, 2001). In this project, we follow the image analysis methods of Ward and McKee (2014) to measure and classify sweetpotatoes by skinning injury levels and subsequently conduct a nonhypothetical (real) Vickrey experimental auction.

Received for publication 20 Mar. 2019. Accepted for publication 22 May 2019.

Published online 2 July 2019.

${ }^{1}$ Department of Agricultural Economics, Mississippi State University, Mississippi State, MS 39762

${ }^{2}$ North Mississippi Research and Extension Center, Pontotoc Ridge-Flatwoods Branch Experiment Station, Mississippi State University, Pontotoc, MS 38863

${ }^{3}$ Department of Agricultural and Biological Engineering, Mississippi State University, Mississippi State, MS 39762

${ }^{4}$ Current affiliation: Department of Biological and Agricultural Engineering, North Carolina State University, Raleigh, NC 27695

${ }^{5}$ Corresponding author. E-mail: stephen.meyers@ msstate.edu.

This is an open access article distributed under the CC BY-NC-ND license (https://creativecommons.org/ licenses/by-nc-nd/4.0/).

https://doi.org/10.21273/HORTTECH04355-19

\section{Materials and methods}

QUANTIFYING SKINNING INJURY. Three commercially packed 40-lb boxes of sweetpotato roots were analyzed to measure skinning severity (Ward and McKee, 2014). To account to some extent for differences in size, firmness, texture, and shape among the products, all products used were Mississippi-grown, USDA No. 1 (USDA, 2005) 'Beauregard' sweetpotatoes. Natural breaks in occurrence of skinning severity were identified. Based on these data, the following five levels of skinning injury were selected for the remainder of the study: $0 \%$ to $<1.0 \%$ skinning injury, $1.0 \%$ to $3.0 \%$, $3.1 \%$ to $5.0 \%, 5.1 \%$ to $7.5 \%$, and $7.6 \%$ to $10.0 \%$. A single representative image of one sweetpotato from each injury level was selected to be used throughout the auctions. The selected image was chosen from a set of images whose skinning incidence aligned with the mode of the data set within each level. Each representative image was also selected to minimize sweetpotato size and shape variation across levels.

EXPERIMENTAL auCTION. After the sweetpotatoes were classified by skinning injury severity level, they were used to conduct a nonhypothetical, incentive-compatible, sealed-bid, Vickrey experimental auction (Lusk and Shogren, 2007; Vickrey, 1961). In a Vickrey auction, the product or service is sold to the highest bidder(s); however, a buyer does not pay the bid she or he submitted but the secondhighest bid instead. This auction mechanism is incentive-compatible, meaning that it gives bidders an incentive to submit a bid equal to their true value for the item being auctioned (Lusk and Shogren, 2007). In addition, a Vickrey auction is a type of sealed-bid auction in which bidders simultaneously submit sealed bids, so that no bidder knows the bids submitted by the other auction participants.

A total of 10 in-person auction sessions were conducted in an experimental economics laboratory in Starkville, MS, over the course of 2 consecutive days. Each session lasted $\approx 1 \mathrm{~h}$ and included between 6 and 16 participants, with a total of 88 participants. The number of participants was subject to our budget constraints, yet previous studies using experimental auctions to elicit consumer preferences for horticultural products have used sample sizes ranging from 74 participants (Yue et al., 2009) to 203 participants (McAdams et al., 2013). Given the number of participants $(88)$, the number of sessions (10) depended in part on two factors: the capacity of the experimental economics laboratory (18 computer stations) and the time availability of participants (McAdams et al., 2013). During each of the $2 \mathrm{~d}$, the experimental sessions were conducted during different times of day (one each in the morning, midmorning, midday, afternoon, and late afternoon) to account for the potential influence of the time of day on consumer preferences for food as in Collart and Interis (2018).

The participants were consumers aged 18 years and older recruited from the local area through multiple advertisements posted multiple times. The advertisements included flyers placed on bulletin boards in coffee shops across town, university-wide e-mail announcements to listservs distributing messages to faculty and staff, and posts in the area's Craigslist's web page (Craigslist, Inc., San Francisco, CA). To ensure that participants were consumers of sweetpotatoes, it was specified in the advertisement and at the time of recruitment that consumption of sweetpotatoes was a criterion for eligibility and that the study would involve consumer decision-making for sweetpotato purchases. It was also specified that an individual may participate in one session total. However, nothing was said about skinning injury or cosmetically different produce to avoid self-selection bias (Yue et al., 2010). The university's Institutional Review Board (IRB) approved this study as protocol IRB no. 15-411 on 26 Apr. 2016, and the study was conducted on 9 and 10 May 2016.

\begin{tabular}{llll}
\hline $\begin{array}{l}\text { Units } \\
\begin{array}{l}\text { To convert U.S. to SI, } \\
\text { multiply by }\end{array}\end{array}$ & U.S. unit & SI unit & $\begin{array}{l}\text { To convert SI to U.S., } \\
\text { multiply by }\end{array}$ \\
\hline 0.4047 & $\mathrm{acre}(\mathrm{s})$ & $\mathrm{ha}$ & 2.4711 \\
45.3592 & $\mathrm{cwt}$ & $\mathrm{kg}$ & 0.0220 \\
2.54 & inch(es) & $\mathrm{cm}$ & 0.3937 \\
0.4536 & $\mathrm{lb}$ & $\mathrm{kg}$ & 2.2046
\end{tabular}


Table 1. Characteristics of participants of an experimental auction for sweetpotatoes conducted at Starkville, MS, on 9 and 10 May 2016 vs. U.S. population.

\begin{tabular}{|c|c|c|c|}
\hline & & $\begin{array}{c}\text { Auction } \\
\text { participants }^{\mathrm{z}}\end{array}$ & $\begin{array}{c}\text { U.S. } \\
\text { population }^{y}\end{array}$ \\
\hline Variable & Category & $(\%)$ & $(\%)$ \\
\hline \multirow[t]{6}{*}{ Age (yr) } & 18 to 24 & 33.0 & 9.7 \\
\hline & 25 to 29 & 28.4 & 7.0 \\
\hline & 30 to 39 & 20.5 & 13.1 \\
\hline & 40 to 49 & 9.1 & 12.8 \\
\hline & 50 to 59 & 4.5 & 13.6 \\
\hline & 60 to 64 & 4.5 & 6.0 \\
\hline \multirow[t]{2}{*}{ Gender } & Female & 59.1 & 50.8 \\
\hline & Male & 40.9 & 49.2 \\
\hline \multirow[t]{2}{*}{ Marital status } & Married & 50.0 & 48.4 \\
\hline & Not married & 50.0 & 51.6 \\
\hline \multirow[t]{2}{*}{ Educational attainment } & $\begin{array}{l}\text { Less than bachelor's } \\
\text { degree }\end{array}$ & 20.5 & 69.1 \\
\hline & $\begin{array}{l}\text { Bachelor's degree or } \\
\text { higher }\end{array}$ & 79.5 & 30.9 \\
\hline \multirow[t]{4}{*}{ Yearly household income } & $\leq \$ 49,999$ & 72.4 & 43.9 \\
\hline & $\$ 50,000$ to $\$ 99,999$ & 17.2 & 30.0 \\
\hline & $\begin{array}{l}\$ 100,000 \text { to } \\
\$ 149,999\end{array}$ & 8.0 & 14.1 \\
\hline & $>\$ 150,000$ & 2.3 & 12.0 \\
\hline \multirow[t]{2}{*}{ Employment $^{x}$} & $\begin{array}{l}\text { Employed part- or } \\
\text { full-time }\end{array}$ & 88.6 & 59.3 \\
\hline & Unemployed & 11.4 & 40.7 \\
\hline \multirow{2}{*}{$\begin{array}{l}\text { Primary grocery shopper of } \\
\text { the household }\end{array}$} & Yes & 93.2 & \\
\hline & No & 6.8 & \\
\hline
\end{tabular}

${ }^{\mathrm{z}}$ Number of participants in each category divided by total number of participants $(\mathrm{n}=88)$. Mean household size is 2.3 people for the participants and 2.4 people for U.S. population. Mean number of children $(<18$ years old $)$ per household is 0.4 for the sample and 0.5 for the population.

y Population means calculated as the corresponding U.S. population divided by total housing units (U.S. Census Bureau. 2017).

${ }^{\mathrm{x}}$ Employment categories are as follows: employed civilian in the labor force or Armed Forces, or civilian in the labor force but unemployed or not in the labor force.

A comparison of the distribution of demographic characteristics of participants with U.S. Census Bureau data (U.S. Census Bureau, 2017) is shown in Table 1. Most participants $(93.2 \%)$ were the primary grocery shopper in their household. The demographics of participants were comparable to the U.S. population in terms of gender, household size, average number of children per household, and marital status. Most participants were women (59.1\%), had an income of less than $\$ 50,000(72.4 \%)$, and were employed part- or full-time $(88.6 \%)$. However, likely because the study was conducted at a university campus, the sample was considerably younger, had a higher educational level, and had a higher employment share relative to the U.S. population.

Each session started with participants checking in and signing a consent form. Participants were informed in the consent form and the initial instructions that they would be participating in a real auction for sweetpotato products. To minimize any potential effect that researcher observation may have on participants' bidding behavior, participants also were assigned an anonymous identification number to be used throughout the study. They then entered the laboratory and chose one of the available computer stations, all of which had privacy panels. Once all participants were ready, they started by reviewing the written instructions and listening to the session monitor explain two examples of multiple-product bidding in a Vickrey or secondprice auction setting. After a moment to ask clarifying questions, subjects participated in two hypothetical practice auction rounds, and immediately thereafter completed a four-question true/false quiz to ensure their understanding of the second-price auction. The auction was programmed in Qualtrics (Provo, UT/Seattle, WA), so participants saw images of the products on the computer screen at an ideal screen image resolution of 72 dots/inch and were able to enter their bids right next to each image. Participants could bid any value, including bids of zero indicating a preference not to purchase the products being auctioned.

In the first multiproduct practice round, participants bid on three different brands of chips and in the second for three different brands of chocolate bars. After all practice bids were submitted and while the participants completed the knowledge quiz, the researchers downloaded the data, randomly selected one of the two practice rounds and one of the three snacks in the selected round to be binding. For the practice round and snack selected, the researchers ordered the bids from highest to lowest and announced what the results would have been had the auction been real. After another moment to ask clarifying questions, participants proceeded to bid concurrently for the five levels of skinning injured sweetpotatoes during two consecutive real auction rounds.

The first real auction round for sweetpotatoes was blind, meaning that participants did not know the actual extent of skinning injury and inferred product quality from visual inspection alone. The second auction round was labeled, meaning that participants were shown the percentage of skinning injury in each set of sweetpotatoes before allowing them to resubmit their bids. Example bidding scenarios for blind and labeled rounds are provided in Figs. 1 and 2, respectively. Of 880 total observations ( 88 participants times two bidding rounds times five sweetpotato products), three bids were missing. Thus, the total number of observations used in the econometric model is 877 . Bidding was followed by an online survey that elicited demographic and other information.

After all bids were submitted and while the participants completed the survey, we randomly selected one of the rounds and one of the five sweetpotato categories to be binding. For the auction round and sweetpotato category selected, we ordered the bids from highest to lowest and, once all participants had completed the survey, announced the anonymous ID of the session's buyer(s) or highest bidder(s) and the market price or second-highest bid. Participants then exited the experimental laboratory and were given a \$35 endowment for participation minus any purchases. If a participant 
ROUND 1. After carefully examining each image, please indicate the maximum amount that you would be willing to pay for 1 pound (lb.) of each of the following items. Write the amount of your bid (in dollars and cents) in the box next to each image. Please be sure to write a bid for each product listed.

Option A

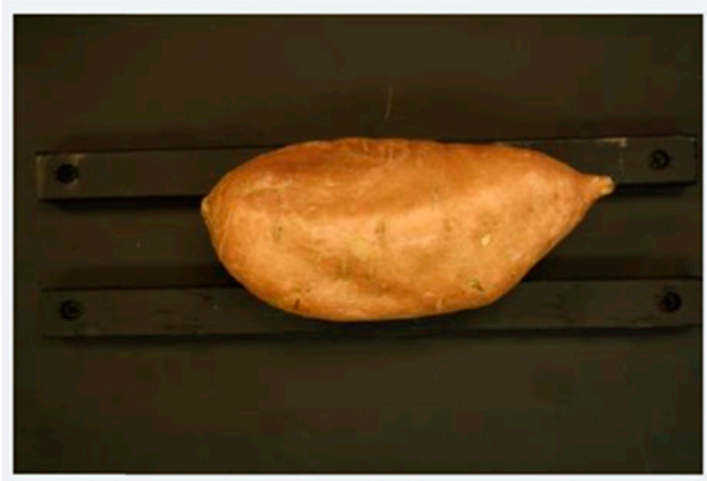

Option B

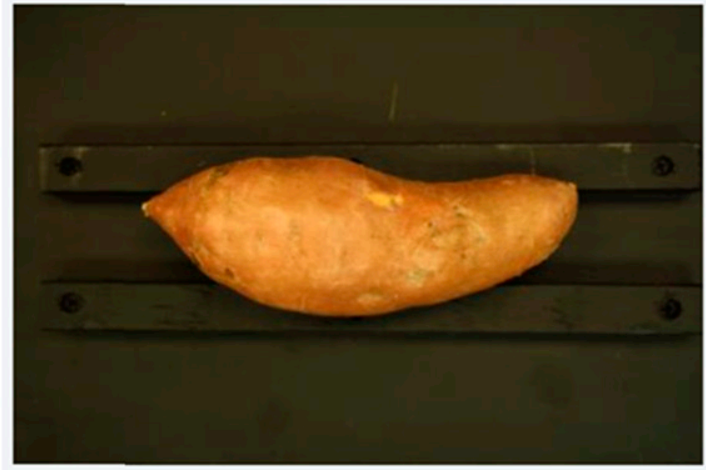

Option C

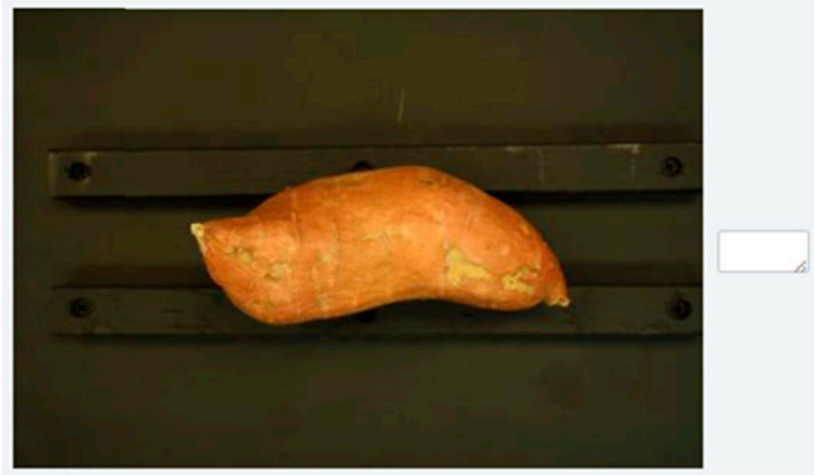

Option D

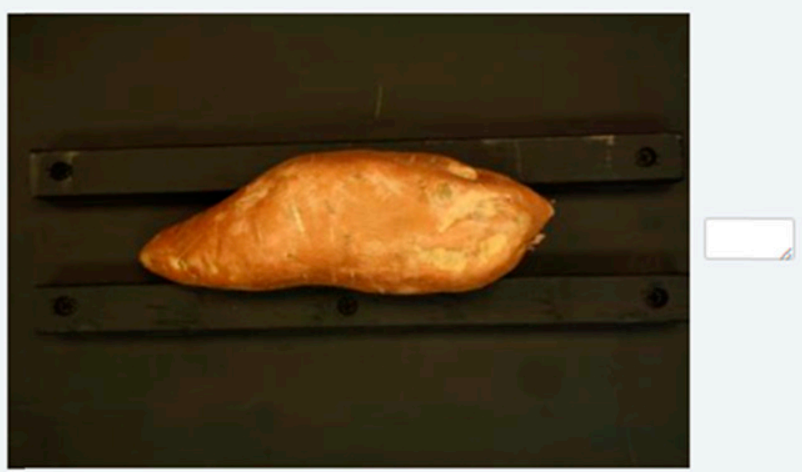

Option E

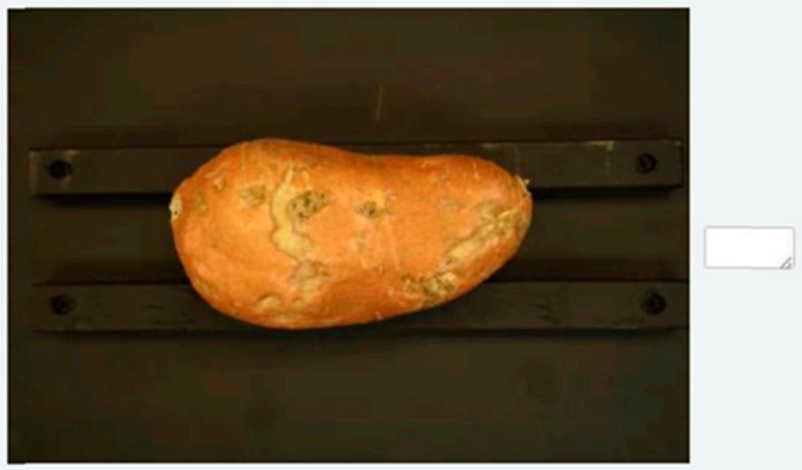

Fig. 1. Screen shot of a blind bidding round conducted at Starkville, MS, on 9 and 10 May 2016 for participants in an experimental auction to determine consumer willingness-to-pay for sweetpotatoes with five different levels of skinning injury severity $(1 \mathrm{lb}=0.4536 \mathrm{~kg}, \$ 1 / \mathrm{lb}=\$ 2.2046 / \mathrm{kg})$.

was a buyer, she or he paid the market price, which was deducted from the initial bidding endowment, and took home the product.

EcONOMETRIC MODEL. Because in most experimental auctions each participant submits multiple bids, the data collected are commonly analyzed using panel data models (Lusk and Shogren, 2007). Panel data have two dimensions of variation: cross-sectional and intertemporal. Thus, experimental auction data can be considered pseudopanel data whereby the number of participants is the cross-sectional dimension and the number of rounds the intertemporal. We specify a random effects linear model (Woolridge, 2010) as follows: 
ROUND 2. After carefully examining each image, please indicate the maximum amount that you would be willing to pay for 1 pound (lb.) of each of the following items. Write the amount of your bid (in dollars and cents) in the box next to each image.

A. Sweet potatoes with 0 to $<1 \%$ skin injury

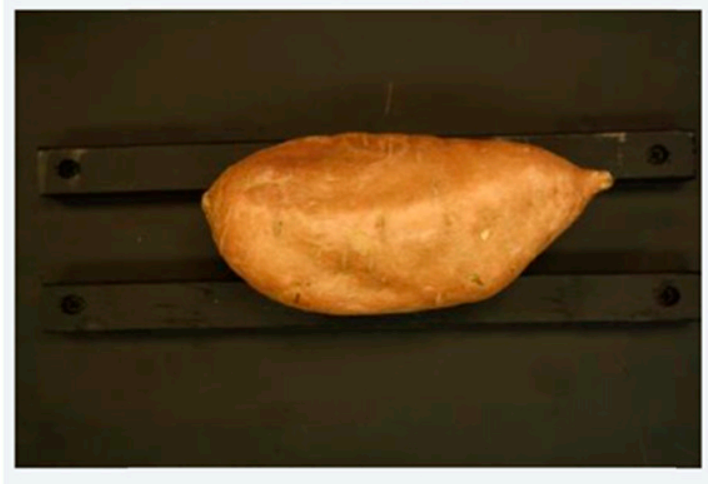

B. Sweet potatoes with $1 \%$ to $3 \%$ skin injury
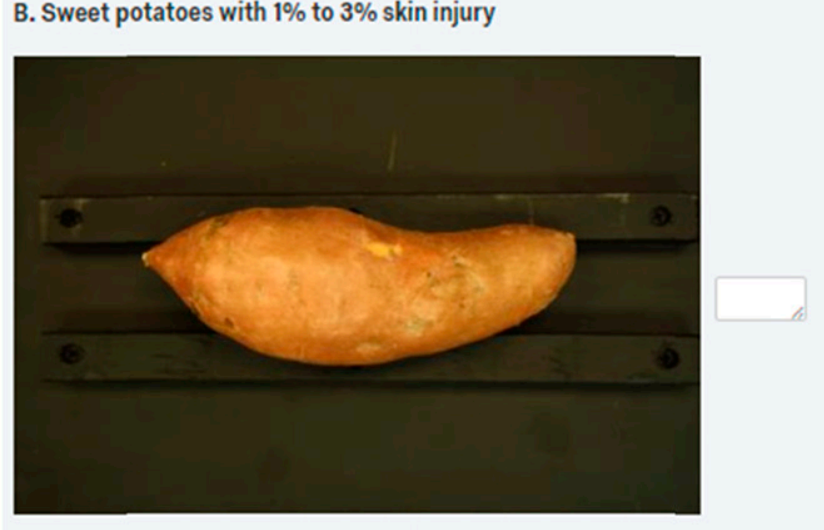

D. Sweet potatoes with $5.1 \%$ to $7.5 \%$ skin injury

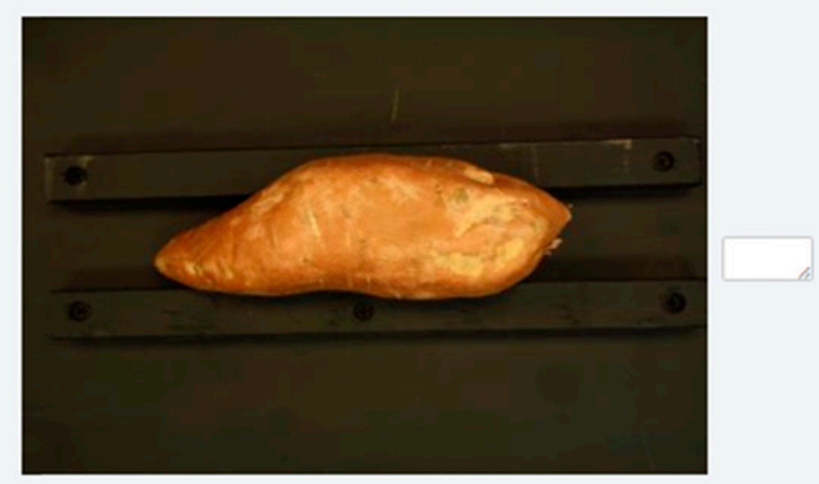

E. Sweet potatoes with $7.5 \%$ to $10 \%$ skin injury

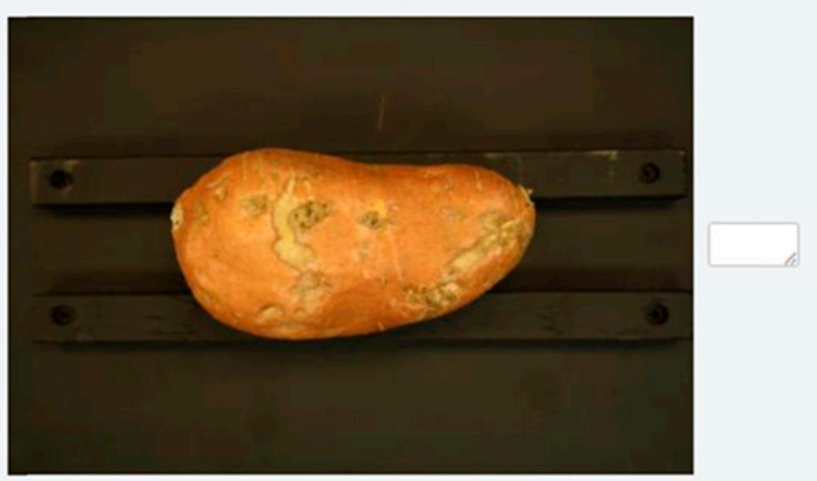

C. Sweet potatoes with $3.1 \%$ to $5 \%$ skin injury

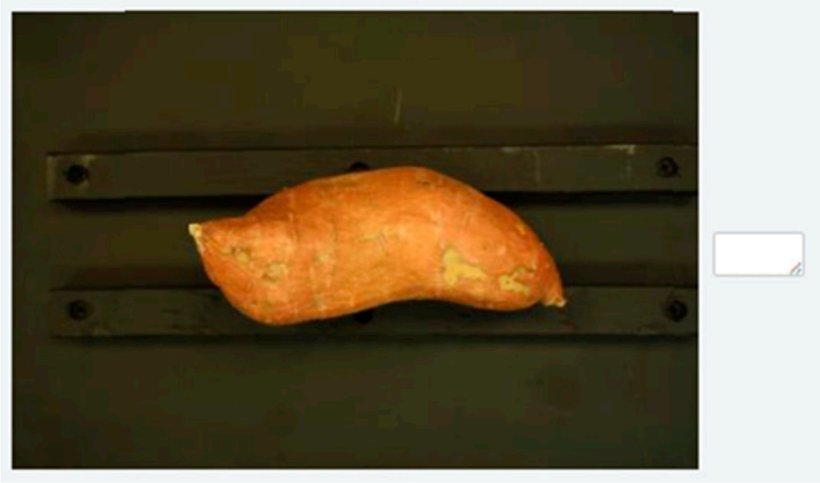

Fig. 2. Screen shot of a labeled bidding round conducted at Starkville, MS, on 9 and 10 May 2016 for participants in an experimental auction to determine consumer willingness-to-pay for sweetpotatoes with five different levels of skinning injury severity $(1 \mathrm{lb}=0.4536 \mathrm{~kg}, \$ 1 / \mathrm{lb}=\$ 2.2046 / \mathrm{kg})$.

$$
\begin{aligned}
& W T P_{i j}=\beta_{0}+\beta_{1, l}\left(\text { Blind } \times \text { Blemish }_{l}\right) \\
& +\beta_{2, l}\left(\text { Labels } \times \text { Blemish }_{l}\right)+u_{i}+e_{i j}
\end{aligned}
$$

where $W T P_{i j}$ is the bid, in U.S. dollars and cents, submitted by participant $i$ in round $j, \beta$ represents parameters to estimate, which include a constant $\beta_{0}$, $l$ is an indicator for the skinning category and is in the set $\{1,2,3,4,5\}$ representing the $0 \%$ to $<1.0 \%, 1.0 \%$ to $3.0 \%, 3.1 \%$ to $5.0 \%, 5.1 \%$ to $7.5 \%$, and $7.6 \%$ to $10.0 \%$ skinning injury levels, respectively. In addition, Blind and Labels are dummy indicators for rounds 1 and 2, respectively, Blemish is a dummy variable that equals 1 when the observation corresponds to 
blemishing level $l, u_{i}$ represents an unobserved round-invariant individual component present in panel data, and $e_{i j}$ is the typical idiosyncratic error term. The SES are clustered at the participant level to account for the potential correlation among the multiple bids submitted by each individual.

\section{Results and discussion}

EXPERIMENTAL AUCTION. Table 2 shows participants' mean bids and their corresponding standard deviation in U.S. dollars for all products in each round. Bids indicate the participants' reservation price, that is, their maximum WTP for $1 \mathrm{lb}$ of each product. As can be seen, participants' mean bids for fresh sweetpotatoes of all skinning levels was positive. In addition, the percentage of zero bids was zero for all products and rounds, suggesting that censoring is not a problem in the data. Recall that participants could bid any value, including bids of zero, indicating a preference not to purchase the products being auctioned.

On average, consumers are willing to pay the most for sweetpotatoes with $0 \%$ to $<1.0 \%$ skinning injury (up to $\$ 1.5 \mathrm{l} / \mathrm{lb}$ to $\$ 1.67 /$ $\mathrm{lb}$ ) and the least for sweetpotatoes with $7.6 \%$ to $10.0 \%$ (up to $\$ 0.76 / \mathrm{lb}$ to $\$ 0.85 / \mathrm{lb}$ ). For any given round (blind or labeled), mean bids continually decreased as the skinning severity level increased. Relative to the lowest skinning injury level $(0 \%$ to $<1.0 \%)$, consumers bidding blindly discounted sweetpotatoes with skinning injury levels of $1.0 \%$ to $3.0 \%$, $3.1 \%$ to $5.0 \%, 5.1 \%$ to $7.5 \%$, and $7.6 \%$ to $10.0 \%$ by $15 \%, 30 \%, 36 \%$, and $44 \%$, respectively. Similarly, when the extent of skinning was labeled, consumers discounted sweetpotatoes with skinning injury levels of $1.0 \%$ to $3.0 \%, 3.1 \%$ to $5.0 \%, 5.1 \%$ to $7.5 \%$, and $7.6 \%$ to $10.0 \%$ by $14 \%$,
$29 \%, 44 \%$, and $54 \%$, respectively. Across rounds (labeled vs. blind), consumers bid higher for sweetpotatoes with skinning injury levels of $\leq 5 \%$ in the labeled compared with blind rounds. When skinning injury was $>5.1 \%$, however, consumers bid higher in the blind compared with labeled rounds. Both Table 2 and Fig. 3 point to differences in participants' bidding behavior across products for a given round and across rounds for a given product; thus, the statistical significance of these differences was explored using a random effects linear model.

Table 3 shows the random effects linear estimates of Eq. [1]. The top of the table shows the results for all the round-blemishing level interactions. The bottom portion of the table shows the value of $\sigma_{u}$, or the SD of the unobserved round-invariant individual component, the value of $\sigma_{e}$, or the SD of the idiosyncratic error term, and the value of $\rho$, or the fraction of the variance due to the round-invariant individual component $u_{i}$. Because the dependent variable in Eq. [1] corresponds to the participant's bid in U.S. dollars, each parameter estimate in Table 3 indicates the effect of the independent variable on WTP. Because all variables are categorical, the effect is interpreted relative to the omitted base category of Blind $\times$ Blemish $_{1}$.

Various effects relative to the omitted base can be directly inferred from observing the coefficients reported in Table 3. When comparing bidding behavior across products given that consumers bid blindly, we find that consumers' WTP was significantly lower by $\$ 0.22, \$ 0.45, \$ 0.54$, and $\$ 0.65$ for sweetpotatoes with skinning injury levels of $1.0 \%$ to $3.0 \%, 3.1 \%$ to $5.0 \%, 5.1 \%$ to $7.5 \%$, and $7.6 \%$ to $10.0 \%$, respectively, relative to the lowest skinning injury level $(0 \%$ to $<1.0 \%)$. When comparing bidding behavior across blind and labeled rounds for a given product, the only direct effect relative to the omitted base $\left(\right.$ Blind $\times$ Blemish $\left._{1}\right)$ that can be directly inferred from the estimates in Table 3 is that of Labels $\times$ Blemish $_{1}$. That is, consumers are willing to pay a statistically significant premium of $\$ 0.17 /$ $\mathrm{lb}$ for sweetpotatoes with $0 \%$ to $<1 \%$ skinning injury when the actual percentages of skinning injury are labeled relative to when they bid blindly. Using the estimated parameters in Table 3 , the bid differences across skinning severity levels for blind and labeled rounds and bid differences between rounds are calculated and reported in Table 4.

As seen in Table 4, when the extent of skinning injury was labeled, consumers' WTP was significantly lower by $\$ 0.24, \$ 0.50, \$ 0.74$, and $\$ 0.92$ for sweetpotatoes with skinning injury levels of $1.0 \%$ to $3.0 \%$, $3.1 \%$ to $5.0 \%, 5.1 \%$ to $7.5 \%$, and $7.6 \%$ to $10.0 \%$, respectively, relative to the lowest skinning injury level $(0 \%$ to $<1 \%)$. Also, when the actual percentages of skinning injury are labeled relative to when they bid blindly, consumers are willing to pay statistically significant premiums of $\$ 0.15 /$ $\mathrm{lb}$ and $\$ 0.12 / \mathrm{lb}$ for sweetpotatoes with $1.0 \%$ to $3.0 \%$ and $3.1 \%$ to $5.0 \%$ skinning injury, respectively, but significantly discount sweetpotatoes with $7.6 \%$ to $10.0 \%$ skinning injury by $\$ 0.10 / \mathrm{lb}$. Labeling the percentage of injury had no effect on consumer preferences for sweetpotatoes with $5.1 \%$ to $7.5 \%$ skinning injury.

MARKETING IMPLICATIONS. Consumers' WTP for fresh sweetpotatoes of all skinning levels in all rounds was positive, even for sweetpotatoes with moderate to high levels of skinning. This suggests that consumers place some positive value on fresh sweetpotatoes with various amounts of skinning injury and may transact if

Table 2. Mean bids and their SD for sweetpotatoes of five skinning injury severity levels in labeled and blind rounds of an experimental auction conducted at Starkville, MS, on 9 and 10 May 2016.

\begin{tabular}{llcccrrr}
\hline & & \multicolumn{5}{c}{ Skinning severity level (\%) } \\
\cline { 3 - 7 } & Round $^{z}$ & $\mathbf{0 ~ t o}<\mathbf{1 . 0}$ & $\mathbf{1 . 0}$ to 3.0 & $\mathbf{3 . 1}$ to 5.0 & $\mathbf{5 . 1}$ to 7.5 & $\mathbf{7 . 6}$ to 10.0 & All \\
\hline Mean bid $(\$ / \mathrm{lb})^{\mathrm{y}}$ & Blind & 1.51 & 1.28 & 1.05 & 0.96 & 0.85 \\
& Labeled & 1.67 & 1.43 & 1.18 & 0.94 & 0.76 \\
SD $(\$ / \mathrm{lb})$ & Blind & 1.02 & 0.88 & 0.84 & 0.78 & 0.83 \\
& Labeled & 1.13 & 1.01 & 0.92 & 0.76 & 0.96 \\
\hline
\end{tabular}

${ }^{\mathrm{z}}$ Experimental auction rounds were either blind or labeled. Blind rounds did not label individual roots that were the subject of bidding with their skinning severity level. Sweetpotatoes in labeled rounds were labeled with their skinning severity level.

${ }^{\mathrm{y}} \$ 1 / \mathrm{lb}=\$ 2.2046 / \mathrm{kg}$. 
the price in the marketplace is equal to or below their WTP. Producers might find marketing the suboptimal sweetpotatoes as economically viable if the expected benefits outweigh the expected costs of bringing them to

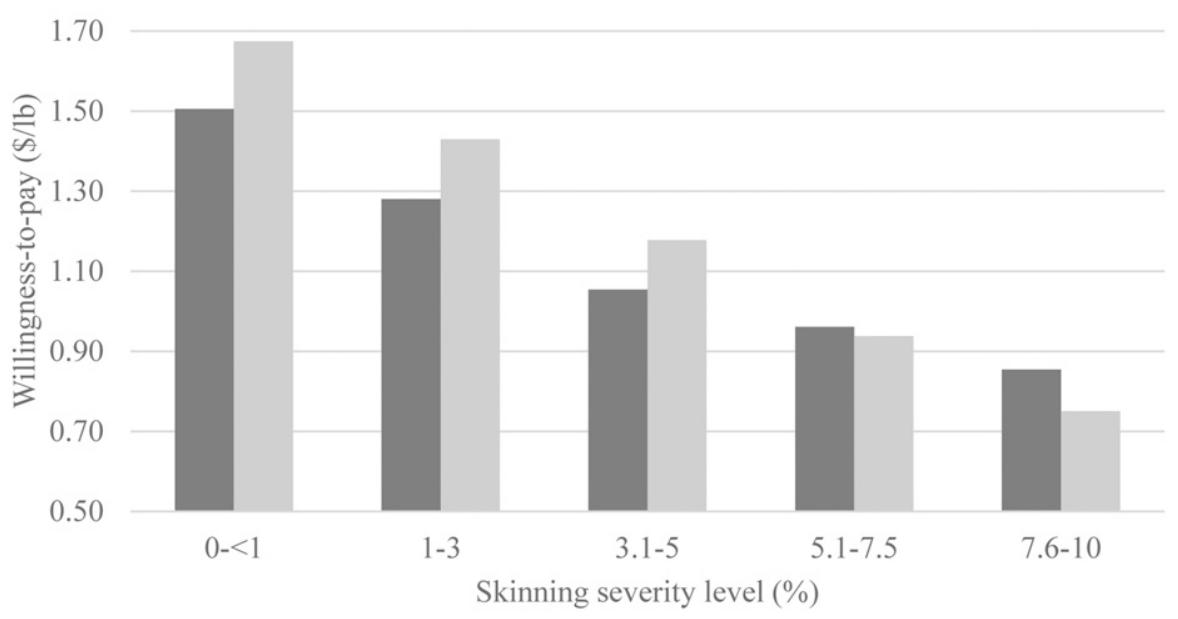

Fig. 3. Total willingness-to-pay for sweetpotatoes of five skinning injury severity levels in labeled and blind rounds of an experimental auction conducted at Starkville, MS, on 9 and 10 May $2016(\$ 1 / 1 b=\$ 2.2046 / \mathrm{kg})$.

Table 3. Random effects linear estimates of an experimental auction to determine consumer willingness-to-pay for sweetpotatoes with five different levels of skinning injury severity conducted at Starkville, MS, on 9 and 10 May 2016.

\begin{tabular}{|c|c|c|}
\hline Variable $^{\mathrm{z}}$ & Parameter & Robust SE \\
\hline Blind $\times$ Blemish $_{2}$ & $-0.224^{* * *}$ & 0.05 \\
\hline${\text { Blind } \times \text { Blemish }_{3}}$ & $-0.451 * * *$ & 0.06 \\
\hline Blind $\times$ Blemish $_{4}$ & $-0.544 * * *$ & 0.07 \\
\hline 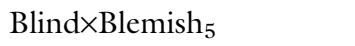 & $-0.650 * * *$ & 0.07 \\
\hline 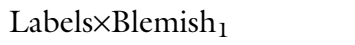 & $0.169 * * *$ & 0.04 \\
\hline 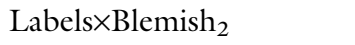 & $-0.076^{* *}$ & 0.04 \\
\hline 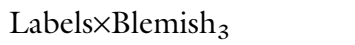 & $-0.327 * * *$ & 0.04 \\
\hline 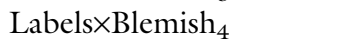 & $-0.567 * * *$ & 0.06 \\
\hline${\text { Labels } \times \text { Blemish }_{5}}$ & $-0.755^{* * *}$ & 0.07 \\
\hline Constant & $1.505 * * *$ & 0.11 \\
\hline Individual term $\mathrm{SD}, \sigma_{u}$ & \multicolumn{2}{|c|}{0.825} \\
\hline Error SD, $\sigma_{e}$ & \multicolumn{2}{|c|}{0.348} \\
\hline Intraclass correlation, $\rho$ & \multicolumn{2}{|c|}{0.849} \\
\hline Groups (no.) & \multicolumn{2}{|c|}{88} \\
\hline Usable observations (no.) & \multicolumn{2}{|c|}{877} \\
\hline
\end{tabular}

${ }^{\mathrm{z}}$ Blind or labels refers to sweetpotatoes identified with the level of skinning severity. Blemish $\mathrm{n}_{\mathrm{n}}$ is increasing level of skinning severity percentage $(0 \%$ to $<1.0 \%, 1.0 \%$ to $3.0 \%, 3.1 \%$ to $5.0 \%, 5.1 \%$ to $7.5 \%, 7.6 \%$ to $10.0 \%$ ). Blind $\times$ Blemish $_{1}$ used as omitted base category.

$* * *,{ }^{*}$ Statistical significance at $1 \%$ and $5 \%$, respectively market; however, they must conduct a cost-benefit analysis that reflects their particular growing and economic conditions.

Interestingly, consumers are willing to pay more for sweetpotatoes with high levels of skinning, from $7.6 \%$ to $10.0 \%$, when bidding blindly compared with when the extent of injury is known, suggesting that skinning levels of $7.6 \%$ and above may not be acceptable by consumers. Marketing visually imperfect produce at a discount is currently being done under different business models in the United States and Europe, through brands and campaigns such as Imperfect Produce (Imperfect Produce, 2018) and Ugly Fruit \& Veg. (The Ugly Fruit \& Veg. Campaign, 2014). Although the authors are not aware of a brand or campaign currently labeling skinning injury in sweetpotatoes at the point of purchase, our results show that a marketing strategy that would let consumers know the extent of injury through labeling would be beneficial for producers (in that consumers would be willing to pay premiums) only for sweetpotatoes with skinning levels of 5\% and below. Future consumer research could look into the benefits of a marketing strategy that brands skinned sweetpotatoes either with binary (e.g., pristine vs. imperfect sweetpotatoes) or gradual labels (e.g., minimally skinned, moderately skinned, imperfect) and examine whether highlighting other product attributes, such as locally grown, may help producers market highly cosmetically flawed sweetpotatoes.

As mentioned previously, skinning injury in sweetpotatoes can result in losses of marketable products due to unattractive marketable appearance but can also create entry points for postharvest plant pathogens and allow for increased water loss. Nondestructive methods to

Table 4. Price premiums and discounts for sweetpotatoes with varying skinning injury levels relative to lowest injury level ( $0 \%$ to $<1 \%$ ) for blind and labeled rounds, and for labeled vs. blind rounds as determined by 88 participants in an experimental auction conducted at Starkville, MS, on 9 and 10 May 2016.

\begin{tabular}{|c|c|c|c|c|c|}
\hline \multirow[b]{3}{*}{ Round $^{\mathrm{z}}$} & \multicolumn{5}{|c|}{ Skinning severity level (\%) } \\
\hline & 0 to $<1.0$ & 1.0 to 3.0 & 3.1 to 5.0 & 5.1 to 7.5 & 7.6 to 10.0 \\
\hline & \multicolumn{5}{|c|}{ Price premiums and discounts $(\$ / \mathrm{lb})$} \\
\hline Labeled & Base & $-0.24 * * *$ & $-0.50 * * *$ & $-0.74 * * *$ & $-0.92 * * *$ \\
\hline Labeled vs. Blind & $0.17 * * *$ & $0.15^{* * *}$ & $0.12 * * *$ & -0.02 & $-0.10 * *$ \\
\hline
\end{tabular}

${ }^{\mathrm{z}}$ Blind or labeled refers to sweetpotatoes identified with the level of skinning severity.

$* * *, * *$ Statistical significance at $1 \%$ and $5 \%$, respectively; $\$ 1 / \mathrm{lb}=\$ 2.2046 / \mathrm{kg}$. 
determine sweetpotato skinning injury severity should be refined so that further research can be conducted to understand the physiological responses associated with skinning injury severity.

WTP estimates can be used in projecting revenue and estimating cost-benefit analyses; however, it is worth highlighting that WTP estimates indicate consumer preferences for these products, and do not directly translate into the price that should be charged. Different products may have different storage and marketing costs, and other market factors, such as seasonality, competition, and costs, which also affect pricing. In addition, the authors acknowledge a common caveat in experimental economics laboratory studies; whereas a laboratory setting allows for control of external factors and helps isolate WTP, other factors related to the experimental context (relative, for example, to observing transactions at a supermarket) may affect the elicited values of WTP for these products. Because the order in which the products are presented to participants may also affect WTP, the reported WTP estimates can potentially be influenced by ordering effects.

Results from this study show that consumers can perceive small gradients of skinning injury on sweetpotatoes, and their WTP varied accordingly. However, we know of no strategies to market fresh sweetpotatoes based on consumer perception of skinning injury severity. Currently, what is considered an allowable percentage of skinning is often determined by the produce retailer. Thus, to maximize marketability of fresh market sweetpotatoes, growers and packers, particularly those without processing contracts, must take precautions to minimize skinning injury during harvest and packing operations, such as those suggested by Edmunds et al. (2008). Growers and packers who excel at packing sweetpotatoes with minimal skinning should use this to their advantage when securing purchase orders and negotiating price with produce retailers.

\section{Literature cited}

Alfnes, F. and K. Rickersten. 2003. European consumers' willingness to pay for
U.S. beef in experimental auction markets. Amer. J. Agr. Econ. 85:396-405.

Alfnes, F. and K. Rickersten. 2008. European consumers' acceptance of US hormone-treated beef. EuroChoices 3(3):1823.

Arancibia, R.A. and D.R. LaBonte. 2013. Skinning, p. 138-139. In C.A. Clark, D.M. Ferrin, T.P. Smith, and G.J. Holmes (eds.). Compendium of sweetpotato diseases, pests, and disorders. Amer. Phytopathol. Soc., St. Paul, MN.

Bouwkamp, J.C., L.E. Scott, and W.L. Harris. 1972. Rapid determination of "skintoughness" in sweetpotato. HortScience 7:473-474.

Collart, A.J. and M.G. Interis. 2018. Consumer imperfect information in the market for expired and nearly expired foods and implications for reducing food waste. Sustainability 10:3835.

Edmunds, B.A., M.D. Boyette, C.A. Clark, D.M. Ferrin, T.P. Smith, and G.J. Holmes. 2008. Postharvest handling of sweetpotatoes. North Carolina Coop. Ext. Serv., Raleigh.

Gallardo, R.K., I. Hanrahan, Y.A. Hong, and J.J. Luby. 2015. Crop load management and the market profitability of 'Honeycrisp' apples. HortTechnology 25:575-584.

Imperfect Produce. 2018. Ugly produce delivered. 9 May 2019. <https://www. imperfectproduce.com $/>$.

List, J.A. and C.A. Gallet. 2001. What experimental protocol influence disparities between actual and hypothetical stated values? Environ. Resources Econ. 20:241-254.

Lusk, J.L. and J.F. Shogren. 2007. Experimental auctions: Methods and applications in economics and marketing research. Cambridge Univ. Press, New York, NY.

McAdams, C., M.A. Palma, C.R. Hall, and A. Ishdorj. 2013. A nonhypothetical ranking and auction mechanism for novel products. J. Agr. Appl. Econ. 45:35-52.

Schultheis, J.R., S.M. Blankenship, D.W. Monks, and M.D. Boyette. 2000. Preharvest methods to reduce skinning in 'Beauregard' sweetpotato. HortScience 35:444.

The Ugly Fruit \& Veg Campaign. 2014. About EndFoodWaste.org. 9 May 2019. <http://www.endfoodwaste.org/about. html>.

U.S. Census Bureau. 2017. 2013-2017 American community survey 5 -year estimates. 9 May 2019. <https://factfinder. census.gov/faces/nav/jsf/pages/ searchresults.xhtml? refresh $=t>$.

U.S. Department of Agriculture. 2005. United States standards for grades of sweet potatoes. 11 Mar. 2019. <https:// www.ams.usda.gov/sites/default/files/ media/Sweetpotato_Standard\%5B1\%5D. pdf $>$.

U.S. Department of Agriculture. 2018. National statistics for sweet potatoes. 1 May 2019. <https://www.nass.usda. gov/Statistics_by_Subject/result.php? 3 B AD BCBE-0F $43-3$ DAD - AE 40 $449 \mathrm{AB} 25 \mathrm{BCFF} 1 \&$ sector $=$ CROPS \& group $=$ VEGETABLES\& $\mathrm{comm}=$ SWEET $\%$ 20POTATOES $>$.

Vickrey, W. 1961. Counterspeculation, auctions and competitive sealed tenders. J. Finance 16:8-37.

Ward, J.K. and C. McKee. 2014. Development of a system to estimate skinning incidence in sweetpotato. Proc. 2014 Amer. Soc. Agr. Biol. Eng. Annu. Mtg.

Wang, X., R.A. Arancibia, J.L. Main, M.W. Shankle, and D.R. LaBonte. 2013. Preharvest foliar applications of ethephon increase skin lignin/suberin content and resistance to skinning in sweetpotato storage roots. HortScience 48:12701274 .

Woolridge, J. 2010. Econometric analysis of cross section and panel data. MIT Press, Cambridge, MA.

Wright, M.E. and D.R. LaBonte. 1994. Surface areas of sweet potatoes using shrink wrap. Appl. Eng. Agr. 10:637693.

Yue, C., F. Alfnes, and H. Jensen. 2009. Discounting spotted apples: Investigating consumers' willingness to accept cosmetic damage in an organic product. J. Agr. Appl. Econ. 41:29-46.

Yue, C., C.R. Hall, B.K. Behe, B.L. Campbell, J.H. Dennis, and R.G. Lopez. 2010. Are consumers willing to pay more for biodegradable containers than for plastic ones? Evidence from hypothetical conjoint analysis and nonhypothetical experimental auctions. J. Agr. Appl. Econ. 42:757-772.

Yue, C., T. Hurley, and N.O. Anderson. 2012. Heterogeneous consumer preferences for native and invasive plants: Evidence from experimental auctions. HortScience 47:1091-1095.

Yue, C., B. Campbell, C. Hall, B. Behe, J. Dennis, and H. Khachatryan. 2015. Consumer preferences for sustainable attributes in plants: Evidence from experimental auctions. Agribusiness 32:222235. 